\title{
Flavobacterium macrobrachii sp. nov., isolated from a freshwater shrimp culture pond
}

\author{
Shih-Yi Sheu, ${ }^{1}$ Tzu-Fang Chiu, ${ }^{1}$ Chiu-Chung Young, ${ }^{2}$ A. B. Arun ${ }^{3}$ \\ and Wen-Ming Chen ${ }^{4}$
}

Correspondence
Wen-Ming Chen
p62365@ms28.hinet.net

The genus Flavobacterium was first established by Frankland in 1889 (Bergey et al., 1923) as part of the family Flavobacteriaceae in the phylum Bacteroidetes (Ludwig et al., 2008). Due to the complex and heterogeneous characteristics of members of the genus, its description has been emended repeatedly over the years (Bernardet et al. 1996, 2002). Members of the genus Flavobacterium are typically Gram-negative, rod-shaped bacteria that display gliding motility and form yellow colonies. Metabolically, members of the genus Flavobacterium are aerobic chemo-organotrophs that can decompose several polysaccharides with the exception of cellulose. Chemotaxonomically, members of the genus possess MK- 6 as the major respiratory quinone, $\mathrm{C}_{15: 0}$,

The GenBank/EMBL/DDBJ accession number for the 16S rRNA gene sequence of strain an-8 ${ }^{\top}$ is FJ593904.

One supplementary figure and one supplementary table are available with the online version of this paper. iso- $\mathrm{C}_{15: 0}$, iso- $\mathrm{C}_{15: 1} \mathrm{G}$, iso- $\mathrm{C}_{15: 0} 3-\mathrm{OH}$, summed feature 4 (iso- $\mathrm{C}_{15: 0} 2-\mathrm{OH}, \mathrm{C}_{16: 1} \omega 7 c$ and/or $\mathrm{C}_{16: 1} \omega 7 t$ ), iso- $\mathrm{C}_{16: 0}$ $3-\mathrm{OH}$, iso- $\mathrm{C}_{17: 1} \omega 9 c$ and iso- $\mathrm{C}_{17: 0} 3-\mathrm{OH}$ as the predominant fatty acids and DNA G $+\mathrm{C}$ contents of between 32 and $37 \mathrm{~mol} \%$ (Bernardet et al. 1996). Members of this genus are physiologically diverse, some showing psychrophilic, psychrotolerant or mesophilic properties and some of which are halophilic, halotolerant or display a sensitivity to salts. Species of the genus Flavobacterium have been isolated from a number of diverse habitats such as freshwater and marine environments, sediments, soils, a glacier and Antarctic lakes (Bernardet et al., 1996; Tamaki et al., 2003; Van Trappen et al., 2003; Zhu et al., 2003; Yi et al., 2005; Wang et al., 2006; Cousin et al., 2007; Weon et al., 2007; Yoon et al., 2007, 2009; Qu et al., 2009).

During the course of a study characterizing microorganisms present in a freshwater pond in the Pingtung

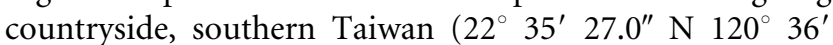
$42.5^{\prime \prime} \mathrm{E}$ ), that was used for culturing giant river shrimp 
(Macrobrachium rosenbergii), a novel bacterium, designated an $-8^{\mathrm{T}}$, which formed yellow-pigmented colonies was isolated and subjected to detailed taxonomic analysis. Strain an $-8^{\mathrm{T}}$ was isolated on R2A agar (BD Difco) after incubation at $25^{\circ} \mathrm{C}$ for 3 days. The strain was maintained on R2A agar at $25{ }^{\circ} \mathrm{C}$ for $48-72 \mathrm{~h}$ by subculturing. On this medium, strain an $-8^{\mathrm{T}}$ was able to grow at $15-30{ }^{\circ} \mathrm{C}$ but not at 10 or $37{ }^{\circ} \mathrm{C}$. Cultures were stored at $-80{ }^{\circ} \mathrm{C}$ in R2A broth with $20 \%(\mathrm{v} / \mathrm{v})$ glycerol or by lyophilization. Flavobacterium terrigena DS- $20^{\mathrm{T}}$ and Flavobacterium terrae R2A1-13 ${ }^{\mathrm{T}}$ were obtained from the DSMZ and KCTC culture collections, respectively, and used as reference strains for phenotypic and genotypic tests.

The $16 \mathrm{~S}$ rRNA gene sequence of strain an $-8^{\mathrm{T}}$ was obtained as described previously by Chen et al. (2001) and analysed by using BioEdit (Hall, 1999) and MEGA version 3.1 software (Kumar et al., 2004), after multiple sequence alignments were performed by using CLUSTAL_X (Thompson et al., 1997). Distances (corrected according to Kimura's twoparameter model; Kimura, 1983) were calculated and clustering was performed using the neighbour-joining method (Saitou \& Nei, 1987). Maximum-likelihood (Felsenstein, 1981) and maximum-parsimony (Kluge \& Farris, 1969) trees were generated by using the treeing algorithms contained in the PHYLIP software package (Felsenstein, 1993). In each case, bootstrap values were calculated based on 1000 replications. The almost-complete $16 \mathrm{~S}$ rRNA gene sequence (1405 bp) of strain an- $8^{\mathrm{T}}$ was compared against $16 \mathrm{~S}$ rRNA gene sequences available from the EzTaxon server (Chun et al., 2007), the Ribosomal Database Project (Maidak et al., 2001) and the GenBank database (http://www.ncbi.nlm.nih.gov/BLAST). 16S rRNA gene sequence analysis indicated that strain an- $8^{\mathrm{T}}$ was a member of the family Flavobacteriaceae of the class Flavobacteria of the phylum Bacteroidetes and formed a distinct subline within the genus Flavobacterium in the neighbour-joining tree (Fig. 1). The phylogenetic trees obtained with the maximum-likelihood and maximumparsimony methods had a similar topology. Sequence similarity calculations (comparing over $1400 \mathrm{bp}$ ) indicated that strain an $-8^{\mathrm{T}}$ was most closely related to $F$. terrigena DS$20^{\mathrm{T}}$ (Yoon et al., 2007) (95.1\% 16S rRNA gene sequence similarity) and F. terrae R2A1-13 ${ }^{\mathrm{T}}$ (Weon et al., 2007)

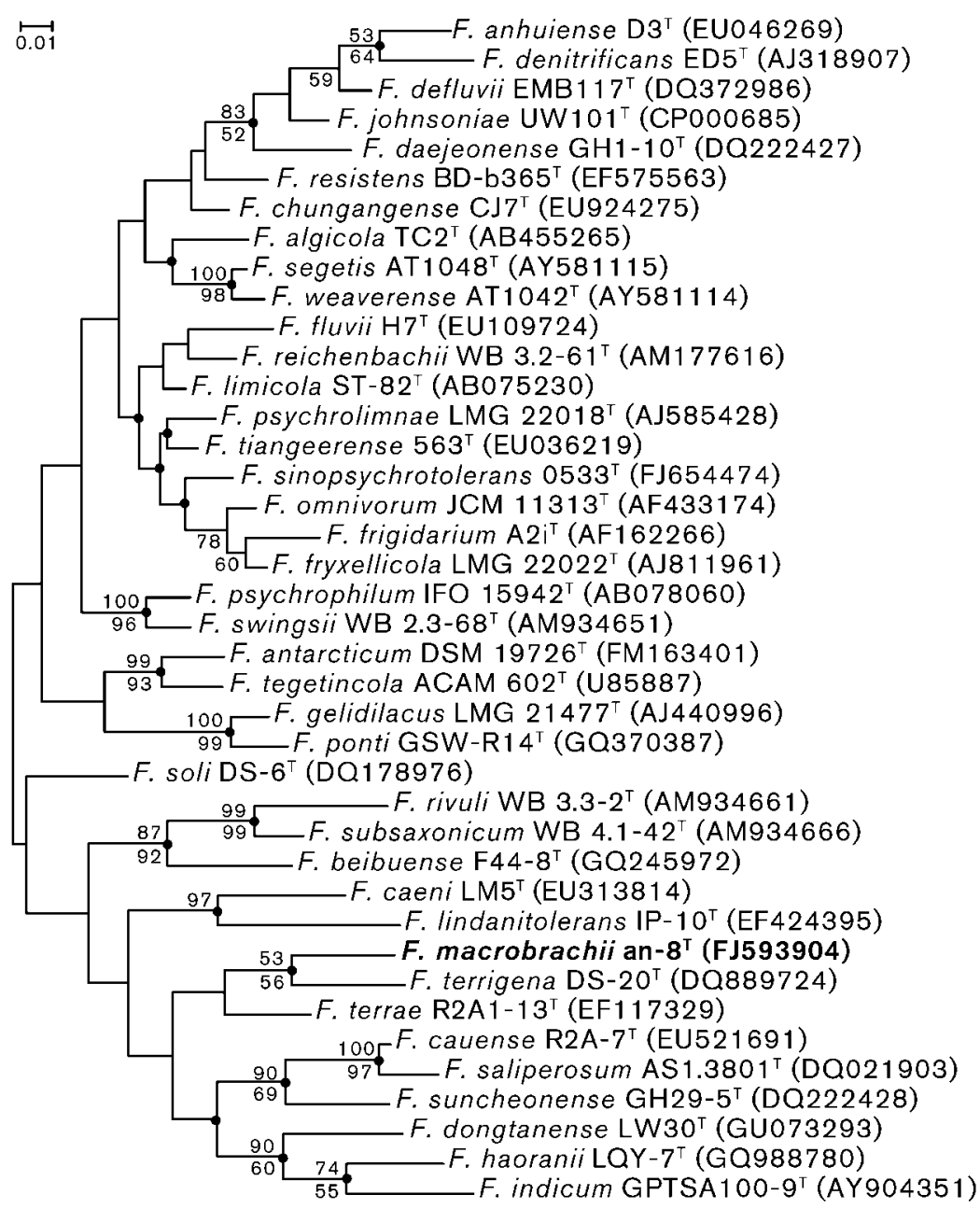

Fig. 1. Neighbour-joining phylogenetic tree based on 16S rRNA gene sequences showing the position of strain an $-8^{\top}$ and closely related species of the genus Flavobacterium. Numbers at nodes are bootstrap percentages $(>50 \%)$ based on the neighbour-joining (above nodes) and maximum-parsimony (below nodes) algorithms. Filled circles indicate branches of the tree that were also recovered using the maximum-likelihood and maximum-parsimony algorithms. Bar, 0.01 substitutions per nucleotide position. 
(94.9\%). Sequence similarities $<94.6 \%$ were observed between strain an $-8^{\mathrm{T}}$ and representative members of other species of the genus Flavobacterium (Fig. 1).

Cell morphology was observed using phase-contrast microscopy (DM 2000; Leica) at lag, exponential and stationary phases of growth. Motility was determined by using the hanging-drop method and Spot Test Flagella Stain (BD Difco) was used for flagellum staining. The presence or absence of gliding motility was determined by using phase-contrast microscopy as described by Bernardet et al. (2002). A Gram Stain Set S kit (BD Difco) and the Ryu non-staining $\mathrm{KOH}$ method (Powers, 1995) were used to test the Gram reaction. Colony morphology was observed on R2A agar by using a stereoscopic microscope (SMZ 800; Nikon).

The $\mathrm{pH}$ range for growth was determined by measuring $\mathrm{OD}_{600}$ of cultures grown in $\mathrm{R} 2 \mathrm{~A}$ broth adjusted to $\mathrm{pH} 3-10$ (intervals of $1 \mathrm{pH}$ unit) prior to sterilization using appropriate biological buffers (Chung et al., 1995). Verification after autoclaving revealed only minor changes in $\mathrm{pH}$. The temperature range for growth was determined on R2A agar at $4,10,15,20,25,30,37,40,45$ and $50{ }^{\circ} \mathrm{C}$. Tolerance of $\mathrm{NaCl}$ was determined by preparing R2A broth according to the formula of the BD Difco medium and adjusting the $\mathrm{NaCl}$ concentration to $0,0.5$ or $1.0-10.0 \%$ $(\mathrm{w} / \mathrm{v})$ (intervals of $1 \%)$. Growth under anaerobic conditions was determined by incubating strain an- $8^{\mathrm{T}}$ in an Oxoid AnaeroGen system.

Strain an $-8^{\mathrm{T}}$ and the two reference strains were examined for activities of catalase, oxidase, DNase, urease and lipase (hydrolysis of corn oil) and for the hydrolysis of starch, casein, chitin, gelatin, agar, urea and Tweens 20, 40, 60 and 80 using standard methods (Gerhardt et al., 1994). Hydrolysis of CM-cellulose was tested as described by Bowman (2000) using R2A agar as the basal medium. The presence of flexirubin-type pigments was determined by using $20 \% \mathrm{KOH}$ (Fautz \& Reichenbach, 1980). Congo red adsorption was determined according to the method of Bernardet et al. (2002). Additional biochemical tests were performed using API ZYM, API $20 \mathrm{E}$ and API 20 NE kits (bioMérieux) and carbon-source utilization was evaluated using a GN2 microplate (Biolog). All commercial phenotypic tests were performed according to the manufacturers' recommendations.

Antibiotic sensitivity was tested by using the disc diffusion method after spreading cell suspensions (0.5 McFarland) on R2A agar (BD Difco). The discs (Oxoid) contained the following antibiotics ( $\mu \mathrm{g}$ per disc): ampicillin (10), chloramphenicol (30), gentamicin (10), kanamycin (30), nalidixic acid (30), novobiocin (30), penicillin G (10), rifampicin (5), streptomycin (10), sulfamethoxazole plus trimethoprim $(23.75: 1.25)$ and tetracycline (30). The diameter of the antibiotic discs used was $8 \mathrm{~mm}$. The effect of antibiotics on cell growth was assessed after 3 days of incubation at $25{ }^{\circ} \mathrm{C}$. A strain was considered susceptible when the diameter of the inhibition zone was $>13 \mathrm{~mm}$, intermediate at $10-12 \mathrm{~mm}$ and resistant at $<10 \mathrm{~mm}$ as described by Nokhal \& Schlegel (1983).

Colonies of strain an $-8^{\mathrm{T}}$ were yellow, round, smooth and convex with entire margins when grown on R2A agar. Strain an $-8^{\mathrm{T}}$ grew well on R2A agar but showed only weak growth when subcultured on nutrient agar (NA; Difco) and did not grow on tryptic soy agar (TSA; Difco). The physiological, biochemical and morphological characteristics of strain an $-8^{\mathrm{T}}$ are given in the species description and Table 1 and in Supplementary Table S1, available in IJSEM Online.

The fatty acid profiles of strain an $-8^{\mathrm{T}}, F$. terrigena DS $-20^{\mathrm{T}}$ and $F$. terrae $\mathrm{R} 2 \mathrm{~A} 1-13^{\mathrm{T}}$ were analysed using cells grown on $\mathrm{R} 2 \mathrm{~A}$ agar at $25{ }^{\circ} \mathrm{C}$ for 3 days. The fatty acid methyl esters were prepared, separated and identified according to the instructions of the Microbial Identification System (MIDI; Sasser, 1990). Although the fatty acid profiles of strains an$8^{\mathrm{T}}$, F. terrigena $\mathrm{DS}-20^{\mathrm{T}}$ and $F$. terrae $\mathrm{R} 2 \mathrm{~A} 1-13^{\mathrm{T}}$ were similar, a few differences were observed in the proportions of some fatty acids (Table 2). The major fatty acids $(>7 \%$ total fatty acids) of strain an- $8^{\mathrm{T}}$ were iso- $\mathrm{C}_{15: 0}$, summed feature $3\left(\mathrm{C}_{16: 1} \omega 6 c\right.$ and/or $\left.\mathrm{C}_{16: 1} \omega 7 c\right)$, iso- $\mathrm{C}_{16: 0} 3-\mathrm{OH}$, iso$\mathrm{C}_{15: 0} 3-\mathrm{OH}$, iso- $\mathrm{C}_{17: 0} 3-\mathrm{OH}$ and iso- $\mathrm{C}_{15: 1}$. Isoprenoid quinones were extracted and purified according to the method of Collins (1985) and were analysed using HPLC. The major respiratory quinone of strain an $-8^{\mathrm{T}}$ was MK-6. The DNA G + C content of strain an $-8^{\mathrm{T}}$, determined by HPLC according to Mesbah et al. (1989), was $39.8 \pm 1.0 \mathrm{~mol} \%$.

Polar lipids were extracted and analysed by two-dimensional TLC as described by Ventosa et al. (1993). Strain an $-8^{\mathrm{T}}$ exhibited a highly similar polar lipid profile to $F$. terrigena DS $-20^{\mathrm{T}}$ and $F$. terrae R2A $1-13^{\mathrm{T}}$, consisting of phosphatidylethanolamine, phosphatidyldimethylethanolamine, phosphatidylserine, and several uncharacterized polar lipids (Supplementary Fig. S1).

Phenotypic examination revealed several common traits between the novel strain and its closest relatives, $F$. terrigena $\mathrm{DS}-20^{\mathrm{T}}$ and $F$. terrae $\mathrm{R} 2 \mathrm{~A} 1-13^{\mathrm{T}}$; however, strain an $-8^{\mathrm{T}}$ could be clearly differentiated from these two species by its colony pigmentation, weak growth on NA, absence of flexirubin-type pigments, ability to hydrolyse Tween 80 , inability to hydrolyse urea and the presence of naphthol-AS-B1-phosphophydrolase activity (Table 1). Strain an $-8^{\mathrm{T}}$ could also be differentiated from $F$. terrigena DS $-20^{\mathrm{T}}$ by its ability to hydrolyse starch and Tweens 40 and 60 and by the absence of cystine arylamidase and trypsin activities. Certain features also distinguish the novel strain from $F$. terrae $\mathrm{R} 2 \mathrm{~A} 1-13^{\mathrm{T}}$, such as the maximum temperature and optimum $\mathrm{NaCl}$ concentration for growth, the inability to grow on TSA and the absence of $\alpha$-glucosidase activity.

Cells of strain an $-8^{\mathrm{T}}$ were Gram-reaction-negative, aerobic, chemo-organotrophic, rod-shaped, non-flagellated and formed yellow-pigmented colonies. Strain an- $8^{\mathrm{T}}$ was 
Table 1. Differential characteristics of strain an $-8^{\top}$ and closely related species of the genus Flavobacterium

Taxa: 1 , strain an $-8^{\mathrm{T}} ; 2$, F. terrigena DS $-20^{\mathrm{T}} ; 3$, F. terrae $\mathrm{R} 2 \mathrm{~A} 1-13^{\mathrm{T}}$. Data for all strains were from this study except for the $\mathrm{G}+\mathrm{C}$ contents of F. terrigena DS $-20^{\mathrm{T}}$ (Yoon et al., 2007) and F. terrae $\mathrm{R} 2 \mathrm{~A} 1-13^{\mathrm{T}}$ (Weon et al., 2007). +, Positive; -, negative; $\mathrm{W}$, weakly positive. All strains were Gram-reaction-negative and positive for oxidase, catalase, alkaline phosphatase, C8 esterase lipase, leucine arylamidase and valine arylamidase activities and hydrolysis of casein, gelatin and DNA. All strains were negative for Congo red adsorption, nitrate reduction, indole production, D-glucose acidification, aesculin hydrolysis, arginine dihydrolase, C4 esterase, C14 lipase, $\alpha$-chymotrypsin, acid phosphatase, $\alpha$ - and $\beta$-galactosidase, $\beta$-glucouronidase, $\beta$-glucosidase, $N$-acetyl- $\beta$-glucosaminidase, $\alpha$-mannosidase, $\alpha$-fucosidase, lipase (hydrolysis of corn oil) activities and assimilation of glucose, arabinose, mannose, mannitol, $\mathrm{N}$-acetylglucosamine, maltose, gluconate, caprate, adipate, malate, citrate, and phenylacetate. All strains were sensitive to ampicillin, chloramphenicol, gentamicin, kanamycin, nalidixic acid, novobiocin, penicillin $\mathrm{G}$, rifampicin, streptomycin and tetracycline and resistant to sulfamethoxazole/trimethoprim.

\begin{tabular}{|c|c|c|c|}
\hline Characteristic & 1 & 2 & 3 \\
\hline Colony pigmentation & Yellow & $\begin{array}{l}\text { Dark } \\
\text { yellow }\end{array}$ & $\begin{array}{c}\text { Yellowish } \\
\text { orange }\end{array}$ \\
\hline $\begin{array}{l}\text { Maximum temperature for growth } \\
\left({ }^{\circ} \mathrm{C}\right)\end{array}$ & 30 & 30 & 40 \\
\hline $\begin{array}{l}\text { Optimum } \mathrm{NaCl} \text { concentration } \\
\text { for growth }(\%, \mathrm{w} / \mathrm{v})\end{array}$ & 0 & 0 & $0-1$ \\
\hline \multicolumn{4}{|l|}{ Growth on: } \\
\hline Nutrient agar & $\mathrm{w}$ & + & + \\
\hline Tryptic soy agar & - & - & + \\
\hline Flexirubin-type pigments & - & + & + \\
\hline \multicolumn{4}{|l|}{ Hydrolysis of: } \\
\hline Casein & $\mathrm{w}$ & + & + \\
\hline Starch & $\mathrm{W}$ & - & + \\
\hline Tweens 40 and 60 & + & - & + \\
\hline Tween 80 & + & - & - \\
\hline DNA & $\mathrm{W}$ & + & + \\
\hline Urea & - & $\mathrm{w}$ & + \\
\hline \multicolumn{4}{|l|}{ Enzymic activities (API ZYM) } \\
\hline Cystine arylamidase & - & + & - \\
\hline Trypsin & - & + & - \\
\hline $\begin{array}{l}\text { Naphthol-AS-B1- } \\
\text { phosphohydrolase }\end{array}$ & + & - & - \\
\hline$\alpha$-Glucosidase & - & - & + \\
\hline DNA G $+C$ content $(\mathrm{mol} \%)$ & 39.8 & 38.2 & 34.0 \\
\hline
\end{tabular}

catalase- and oxidase positive, could decompose gelatin, casein, starch, Tweens 40, 60 and 80 and could not produce indole. The predominant cellular fatty acids were iso- $\mathrm{C}_{15: 0}$, summed feature $3\left(\mathrm{C}_{16: 1} \omega 6 c\right.$ and/or $\left.\mathrm{C}_{16: 1} \omega 7 c\right)$, iso- $\mathrm{C}_{16: 0} 3$ $\mathrm{OH}$, iso- $\mathrm{C}_{15: 0} 3-\mathrm{OH}$, iso- $\mathrm{C}_{17: 0} 3-\mathrm{OH}$ and iso- $\mathrm{C}_{15: 1}$ and the major respiratory quinone was MK- 6 . On the basis of these characteristics, which were consistent with the description of the genus Flavobacterium (Bernardet et al. 1996), and the data obtained from $16 \mathrm{~S}$ rRNA gene sequence comparisons, strain an $-8^{\mathrm{T}}$ occupied a distinct position within the genus
Table 2. Cellular fatty acid compositions of strain an- $8^{\top}$ and closely related species of the genus Flavobacterium

Taxa: 1 , strain an $-8^{\mathrm{T}} ; 2$, F. terrigena DS- $20^{\mathrm{T}} ; 3$, F terrae $\mathrm{R} 2 \mathrm{~A} 1-13^{\mathrm{T}}$. All data obtained in this study. Strains were grown on R2A agar at $25{ }^{\circ} \mathrm{C}$ for 3 days. Values are percentages of the total fatty acids. -, Not detected. Fatty acids representing $<1 \%$ are not shown. For unsaturated fatty acids, the position of the double bond is located by counting from the methyl $(\omega)$ end of the carbon chain.

\begin{tabular}{|c|c|c|c|}
\hline Fatty acid & 1 & 2 & 3 \\
\hline iso- $\mathrm{C}_{10: 0}$ & 1.0 & - & - \\
\hline anteiso- $\mathrm{C}_{11: 0}$ & - & 1.5 & 1.1 \\
\hline anteiso- $\mathrm{C}_{12: 0}$ & - & 1.4 & 1.0 \\
\hline $\mathrm{C}_{12: 0}$ & - & - & 1.2 \\
\hline iso- $\mathrm{C}_{13: 0}$ & - & 1.0 & 1.6 \\
\hline iso- $\mathrm{C}_{14: 0}$ & 1.4 & 1.0 & 5.5 \\
\hline $\mathrm{C}_{14: 0}$ & 2.1 & 1.1 & 1.1 \\
\hline iso- $\mathrm{C}_{14: 0} 3-\mathrm{OH}$ & - & - & 1.3 \\
\hline iso- $\mathrm{C}_{15: 1}$ & 7.6 & 10.7 & 10.6 \\
\hline iso- $\mathrm{C}_{15: 0}$ & 18.1 & 28.8 & 18.1 \\
\hline anteiso- $C_{15: 0}$ & 2.1 & 2.4 & 4.1 \\
\hline iso- $\mathrm{C}_{15: 0} 3-\mathrm{OH}$ & 8.8 & 7.1 & 6.3 \\
\hline $\mathrm{C}_{15: 0} 2-\mathrm{OH}$ & 1.6 & - & - \\
\hline $\mathrm{C}_{15: 0} 3-\mathrm{OH}$ & 2.6 & - & 1.3 \\
\hline $\mathrm{C}_{15: 1} \omega 6 c$ & 3.7 & 3.4 & - \\
\hline iso- $\mathrm{C}_{16: 1}$ & 1.1 & - & - \\
\hline iso- $\mathrm{C}_{16: 0}$ & 4.5 & 3.4 & 17.2 \\
\hline $\mathrm{C}_{16: 0}$ & 5.5 & 2.9 & 2.7 \\
\hline iso- $\mathrm{C}_{16: 0} 3-\mathrm{OH}$ & 9.1 & 1.5 & 6.4 \\
\hline $\mathrm{C}_{16: 0} 3-\mathrm{OH}$ & 4.2 & 2.3 & 1.4 \\
\hline iso- $\mathrm{C}_{17: 1} \omega 9 c$ & 1.3 & 6.2 & 4.4 \\
\hline iso- $\mathrm{C}_{17: 0} 3-\mathrm{OH}$ & 7.9 & 11.1 & 8.4 \\
\hline $\mathrm{C}_{17: 0} 3-\mathrm{OH}$ & 1.3 & - & - \\
\hline $\mathrm{C}_{18: 1} \omega 9 c$ & - & 4.1 & - \\
\hline $\mathrm{C}_{18: 0}$ & 1.7 & 1.0 & 1.3 \\
\hline Summed feature $3^{\star}$ & 9.6 & 5.1 & 1.3 \\
\hline
\end{tabular}

* Summed features are groups of two or three fatty acids that cannot be separated by GLC using the MIDI system. Summed feature 3 comprises $\mathrm{C}_{16: 1} \omega 6 c$ and/or $\mathrm{C}_{16: 1} \omega 7 c$.

Flavobacterium. Based on its phylogenetic position and phenotypic characteristics along with the unique combination of chemotaxonomic and biochemical properties (Table 1 and Table 2), strain an- $8^{\mathrm{T}}$ represents a novel species of the genus Flavobacterium, for which the name Flavobacterium macrobrachii sp. nov., is proposed.

\section{Description of Flavobacterium macrobrachii sp. nov.}

Flavobacterium macrobrachii (ma.cro.brach'i.i. N.L. gen. n. macrobrachii of Macrobrachium, a genus of freshwater shrimp, isolated from the surrounding environment of shrimp belonging to the genus Macrobrachium.)

Cells are Gram-reaction-negative, aerobic, non-flagellated, non-motile and rod-shaped. After $48 \mathrm{~h}$ of incubation at 
$25{ }^{\circ} \mathrm{C}$ on R2A agar, cell size is $0.3-0.5 \times 0.8-2.0$. Colonies on R2A agar are yellow, round, smooth and convex, have entire margins and are $\sim 0.8-1.5 \mathrm{~mm}$ in diameter after $72 \mathrm{~h}$ of incubation at $25{ }^{\circ} \mathrm{C}$. Growth occurs at $15-30{ }^{\circ} \mathrm{C}$ (optimum $25^{\circ} \mathrm{C}$ ), at $\mathrm{pH} 7-8$ (optimum $\mathrm{pH}$ 8) and in $0-1 \%(\mathrm{w} / \mathrm{v})$ $\mathrm{NaCl}$ (optimum $0 \%$ ). Oxidase- and catalase positive. Positive for hydrolysis of casein, starch, DNA and Tweens 40, 60 and 80. Negative for lipase and urease activities and hydrolysis of chitin, CM-cellulose and agar. Congo red adsorption is negative and flexirubin-type pigments are not present. In API $20 \mathrm{NE}$ tests, positive for gelatin hydrolysis but negative for nitrate reduction, indole production, D-glucose acidification, aesculin hydrolysis, arginine dihydrolase, urease and $\beta$-galactosidase activities and assimilation of all carbohydrates tested. In API $20 \mathrm{E}$ tests, positive for gelatin hydrolysis but negative for hydrogen sulfide production, ONPG hydrolysis, nitrate reduction, indole production, urea hydrolysis, acetoin production, citrate and malonate utilization, glucose, mannitol, xylose, myo-inositol, sorbitol, rhamnose, sucrose, lactose, arabinose, adonitol, raffinose and salicin fermentation and lysine decarboxylase, ornithine decarboxylase, tryptophan deaminase and arginine dihydrolase activities. In the API ZYM system, positive for alkaline phosphatase, C8 lipase, leucine arylamidase, valine arylamidase and naphthol-AS-B1-phosphophydrolase activities but negative for $\mathrm{C} 4$ esterase, C14 lipase, cystine arylamidase, trypsin, $\alpha$-chymotrypsin, acid phosphatase, $\alpha$ - and $\beta$-galactosidase, $\beta$-glucuronidase, $\alpha$ - and $\beta$-glucosidase, $\quad N$-acetyl- $\beta$-glucosaminidase, $\alpha$-mannosidase and $\alpha$-fucosidase activities. The following compounds are utilized as sole carbon sources in the GN2 microplate system: $\alpha$-cyclodextrin, dextrin, glycogen, Tweens 40 and 80 , $\alpha$-D-glucose, $\alpha$-lactose, maltose, D-mannose, sucrose, acetic acid, L-alanyl glycine, L-glutamic acid, glycyl L-aspartic acid, glycyl L-glutamic acid, L-proline, L-threonine, urocanic acid, inosine and uridine. All other substrates in the GN2 microplate system are not utilized. Sensitive to ampicillin, chloramphenicol, gentamicin, kanamycin, nalidixic acid, novobiocin, penicillin G, rifampicin, streptomycin and tetracycline but resistant to sulfamethoxazole/trimethoprim. The major fatty acids are iso- $C_{15: 0}$, summed feature 3 $\left(\mathrm{C}_{16: 1} \omega 6 c\right.$ and/or $\left.\mathrm{C}_{16: 1} \omega 7 c\right)$, iso- $\mathrm{C}_{16: 0} 3-\mathrm{OH}$, iso- $\mathrm{C}_{15: 0}$ $3-\mathrm{OH}$, iso- $\mathrm{C}_{17: 0} 3-\mathrm{OH}$ and iso- $\mathrm{C}_{15: 1}$. The major respiratory quinone is MK-6. The polar lipid profile comprises phosphatidylethanolamine, phosphatidyldimethylethanolamine, phosphatidylserine and several uncharacterized polar lipids.

The type strain, an $-8^{\mathrm{T}}\left(=\right.$ BCRC $\left.17965^{\mathrm{T}}=\mathrm{LMG} 25203^{\mathrm{T}}\right)$, was isolated from a freshwater culture pond in the Pingtung countryside, southern Taiwan, which was used for culturing giant river shrimp. The DNA G $+\mathrm{C}$ content of the type stain is $39.8 \mathrm{~mol} \%$.

\section{References}

Bergey, D. H., Harrison, F. C., Breed, R. S., Hammer, B. W. \& Huntoon, F. M. (editors) (1923). Genus II. Flavobacterium gen. nov.
In Bergey's Manual of Determinative Bacteriology, 1st edn., pp. 97-117. Baltimore: Williams \& Wilkins.

Bernardet, J.-F., Segers, P., Vancanneyt, M., Berthe, F., Kersters, K. \& Vandamme, P. (1996). Cutting a Gordian knot: emended classification and description of the genus Flavobacterium, emended description of the family Flavobacteriaceae, and proposal of Flavobacterium hydatis nom. nov. (Basonym, Cytophaga aquatilis Strohl and Tait 1978). Int J Syst Bacteriol 46, 128-148.

Bernardet, J.-F., Nakagawa, Y., Holmes, B. \& Subcommittee on the taxonomy of Flavobacterium and Cytophaga-like bacteria of the International Committee on Systematics of Prokaryotes (2002). Proposed minimal standards for describing new taxa of the family Flavobacteriaceae and emended description of the family. Int J Syst Evol Microbiol 52, 1049-1070.

Bowman, J. P. (2000). Description of Cellulophaga algicola sp. nov., isolated from the surfaces of Antarctic algae, and reclassification of Cytophaga uliginosa (ZoBell and Upham 1944) Reichenbach 1989 as Cellulophaga uliginosa comb. nov. Int J Syst Evol Microbiol 50, 18611868.

Chen, W. M., Laevens, S., Lee, T. M., Coenye, T., De Vos, P., Mergeay, M. \& Vandamme, P. (2001). Ralstonia taiwanensis sp. nov., isolated from root nodules of Mimosa species and sputum of a cystic fibrosis patient. Int J Syst Evol Microbiol 51, 1729-1735.

Chun, J., Lee, J.-H., Jung, Y., Kim, M., Kim, S., Kim, B. K. \& Lim, Y. W. (2007). EzTaxon: a web-based tool for the identification of prokaryotes based on 16S ribosomal RNA gene sequences. Int J Syst Evol Microbiol 57, 2259-2261.

Chung, Y. C., Kobayashi, T., Kanai, H., Akiba, T. \& Kudo, T. (1995). Purification and properties of extracellular amylase from the hyperthermophilic archeon Thermococccus profundus DT5432. Appl Environ Microbiol 61, 1502-1506.

Collins, M. D. (1985). Isoprenoid quinone analysis in classification and identification. In Chemical Methods in Bacterial Systematics, pp. 267-287. Edited by M. Goodfellow \& D. E. Minnikin. London: Academic Press.

Cousin, S., Päuker, O. \& Stackebrandt, E. (2007). Flavobacterium aquidurense sp. nov. and Flavobacterium hercynium sp. nov., from a hard-water creek. Int J Syst Evol Microbiol 57, 243-249.

Fautz, E. \& Reichenbach, J. R. (1980). A simple test for flexirubintype pigments. FEMS Microbiol Lett 8, 87-91.

Felsenstein, J. (1981). Evolutionary trees from DNA sequences: a maximum likelihood approach. J Mol Evol 17, 368-376.

Felsenstein, J. (1993). PHYLIP (phylogeny inference package), version 3.5c. Distributed by the author. Department of Genome Sciences, University of Washington, Seattle, USA.

Gerhardt, P., Murray, R. G. E., Wood, W. A. \& Krieg, N. R. (editors) (1994). Methods for General and Molecular Bacteriology. Washington, DC: American Society for Microbiology.

Hall, T. A. (1999). BioEdit: a user-friendly biological sequence alignment editor and analysis program for Windows 95/98/NT. Nucleic Acids Symp Ser 41, 95-98.

Kimura, M. (1983). The Neutral Theory of Molecular Evolution. Cambridge: Cambridge University Press.

Kluge, A. G. \& Farris, F. S. (1969). Quantitative phyletics and the evolution of anurans. Syst Zool 18, 1-32.

Kumar, S., Tamura, K. \& Nei, M. (2004). MEGA3: integrated software for molecular evolutionary genetics analysis and sequence alignment. Brief Bioinform 5, 150-163.

Ludwig, W., Euzéby, J. \& Whitman, W. B. (2008). The Bacteroidetes, Planctomycetes, Chlamydiae, Spirochaetes, Fibrobacteres, Fusobacteria, Acidobacteria, Verrucomicrobia, Dictyoglomi, and Gemmatimonadetes. 
In Bergey's Manual of Systematic Bacteriology, 2nd edn, vol. 4. Edited by N. R. Krieg, J. T. Staley, B. Hedlund, B. J. Paster, N. Ward, W. Ludwig \& W. B. Whitman. New York: Springer.

Maidak, B. L., Cole, J. R., Lilburn, T. G., Parker, C. T., Jr, Saxman, P. R., Farris, R. J., Garrity, G. M., Olsen, G. J., Schmidt, T. M. \& Tiedje, J. M. (2001). The RDP-II (Ribosomal Database Project). Nucleic Acids Res 29, 173-174.

Mesbah, M., Premachandran, U. \& Whitman, W. B. (1989). Precise measurement of the $\mathrm{G}+\mathrm{C}$ content of deoxyribonucleic acid by highperformance liquid chromatography. Int J Syst Bacteriol 39, 159-167.

Nokhal, T. H. \& Schlegel, H. G. (1983). Taxonomic study of Paracoccus denitrijicans. Int J Syst Bacteriol 33, 26-37.

Powers, E. M. (1995). Efficacy of the Ryu nonstaining KOH technique for rapidly determining Gram reactions of food-borne and waterborne bacteria and yeasts. Appl Environ Microbiol 61, 3756-3758.

Qu, J. H., Yuan, H. L., Li, H. F. \& Deng, C. P. (2009). Flavobacterium cauense sp. nov., isolated from sediment of a eutrophic lake. Int J Syst Evol Microbiol 59, 2666-2669.

Saitou, N. \& Nei, M. (1987). The neighbor-joining method: a new method for reconstructing phylogenetic trees. Mol Biol Evol 4, 406-425.

Sasser, M. (1990). Identification of bacteria by gas chromatography of cellular fatty acids. Newark, DE: MIDI Inc.

Tamaki, H., Hanada, S., Kamagata, Y., Nakamura, K., Nomura, N., Nakano, K. \& Matsumura, M. (2003). Flavobacterium limicola sp. nov., a psychrophilic, organic-polymer-degrading bacterium isolated from freshwater sediments. Int J Syst Evol Microbiol 53, 519-526.

Thompson, J. D., Gibson, T. J., Plewniak, F., Jeanmougin, F. \& Higgins, D. G. (1997). The CLUSTAL_X windows interface: flexible strategies for multiple sequence alignment aided by quality analysis tools. Nucleic Acids Res 25, 4876-4882.
Van Trappen, S., Mergaert, J. \& Swings, J. (2003). Flavobacterium gelidilacus sp. nov., isolated from microbial mats in Antarctic lakes. Int J Syst Evol Microbiol 53, 1241-1245.

Ventosa, A., Marquez, M. C., Kocur, M. \& Tindall, B. J. (1993). Comparative study of "Micrococcus sp." strains CCM 168 and CCM 1405 and members of the genus Salinicoccus. Int J Syst Bacteriol 43, 245-248.

Wang, Z.-W., Liu, Y.-H., Dai, X., Wang, B.-J., Jiang, C.-Y. \& Liu, S.-J. (2006). Flavobacterium saliperosum sp. nov., isolated from freshwater lake sediment. Int J Syst Evol Microbiol 56, 439-442.

Weon, H. Y., Song, M. H., Son, J. A., Kim, B. Y., Kwon, S. W., Go, S. J. \& Stackebrandt, E. (2007). Flavobacterium terrae sp. nov. and Flavobacterium cucumis sp. nov., isolated from greenhouse soil. Int J Syst Evol Microbiol 57, 1594-1598.

Yi, H., Oh, H.-M., Lee, J.-H., Kim, S.-J. \& Chun, J. (2005). Flavobacterium antarcticum sp. nov., a novel psychrotolerant bacterium isolated from the Antarctic. Int J Syst Evol Microbiol 55, 637-641.

Yoon, J. H., Kang, S. J., Lee, J. S. \& Oh, T. K. (2007). Flavobacterium terrigena sp. nov., isolated from soil. Int J Syst Evol Microbiol 57, 947950.

Yoon, H. S., Aslam, Z., Song, G. C., Kim, S. W., Jeon, C. O., Chon, T. S. \& Chung, Y. R. (2009). Flavobacterium sasangense sp. nov., isolated from a wastewater stream polluted with heavy metals. Int J Syst Evol Microbiol 59, 1162-1166 [Retraction: Int J Syst Evol Microbiol (2010), 60, 267-268].

Zhu, F., Wang, S. \& Zhou, P. J. (2003). Flavobacterium xinjiangense sp. nov. and Flavobacterium omnivorum sp. nov., novel psychrophiles from the China No. 1 glacier. Int J Syst Evol Microbiol 53, 853857. 